\title{
Brexit and Financial Services
}

\author{
John Armour*
}

\section{Financial services in the UK and the EU}

'Financial services' comprise all the activities undertaken in the financial system-the sector that channels savings from consumers toward firms and households that need finance for investment or current consumption. It includes banks, asset managers, financial markets, and insurance. Financial services are a very important sector of the UK's economy, accounting for between $7-12 \%$ of GDP, $11 \%$ of gross tax receipts, and $7-12 \%$ of employment (Kirby, 2016; TheCityUK, 2016). ${ }^{1}$ Financial services also provide the largest trade surplus for any sector of the UK economy, valued at $£ 72$ billion in 2014 , of which $£ 19$ billion is with the rest of the EU (TheCityUK, 2016).

Table 1: EU component of UK financial services revenue, by sector $(2015, \mathrm{fbn})$

\begin{tabular}{|l|c|c|c|c|c|}
\hline \multicolumn{1}{|c|}{ Sector } & Banking & $\begin{array}{c}\text { Asset } \\
\text { management }\end{array}$ & Insurance & $\begin{array}{c}\text { Market } \\
\text { infrastructure }\end{array}$ & Total \\
\hline Intra-EU revenues & 27 & 6 & 5 & 12 & 50 \\
\hline Total revenues & 117 & 23 & 42 & 26 & 208 \\
\hline $\begin{array}{l}\text { EU fraction of total } \\
\text { sector revenues }\end{array}$ & 0.23 & 0.26 & 0.12 & 0.46 & 0.24 \\
\hline $\begin{array}{l}\text { Sector fraction of } \\
\text { total EU revenues }\end{array}$ & 0.54 & 0.12 & 0.10 & 0.24 & 1.00 \\
\hline
\end{tabular}

Notes: Revenue data are from a study conducted by Oliver Wyman, reported in TheCityUK (2016). 'Intra-EU revenues' comprise UK financial services revenues from international and wholesale business related to the EU; 'Insurance' includes reinsurance; 'Market infrastructure' includes other financial services.

Table 1 reports UK revenues for different types of financial service during 2015, and the component of these generated by intra-EU international business. As can be seen, banking is by far the largest sector overall and accounts for $54 \%$ of intra-EU financial

\footnotetext{
* Hogan Lovells Professor of Law and Finance, University of Oxford and Research Fellow, European Corporate Governance Institute. I am grateful to Luca Enriques for thoughtful comments on an earlier version of this paper. The remaining errors are my own.

${ }^{1}$ Although it is common to think of this as an issue for 'the City', two thirds of these employees are based outside London.
} 
services revenue. However, it is notable that a smaller proportion of the UK's total banking revenues are intra-EU (23\%) than for market infrastructure $(46 \%)$ or even asset management (26\%).

Sectoral differences also matter from the perspective of the EU, as Figure 1 illustrates. This shows the proportion of total EU28 activity of various types taking place in the UK. As a baseline, the UK accounts for $17 \%$ of the entire EU GDP. This is closely tracked by the fraction of EU bank assets held by UK banks (21\%). However, the UK's share of total EU activity grows as we move to the right of Figure 1, encompassing equity market capitalisation (30\%), numbers of globally systemically important banks (31\%) and especially wholesale market activities. Table 1 and Figure 1 together suggest that while banking is the largest component of the UK's intra-EU financial services revenues, the UK's greatest intraEU comparative advantage lies in asset management and wholesale markets.

Figure 1: Percentage of EU-wide activity taking place in UK, by sector (2015).

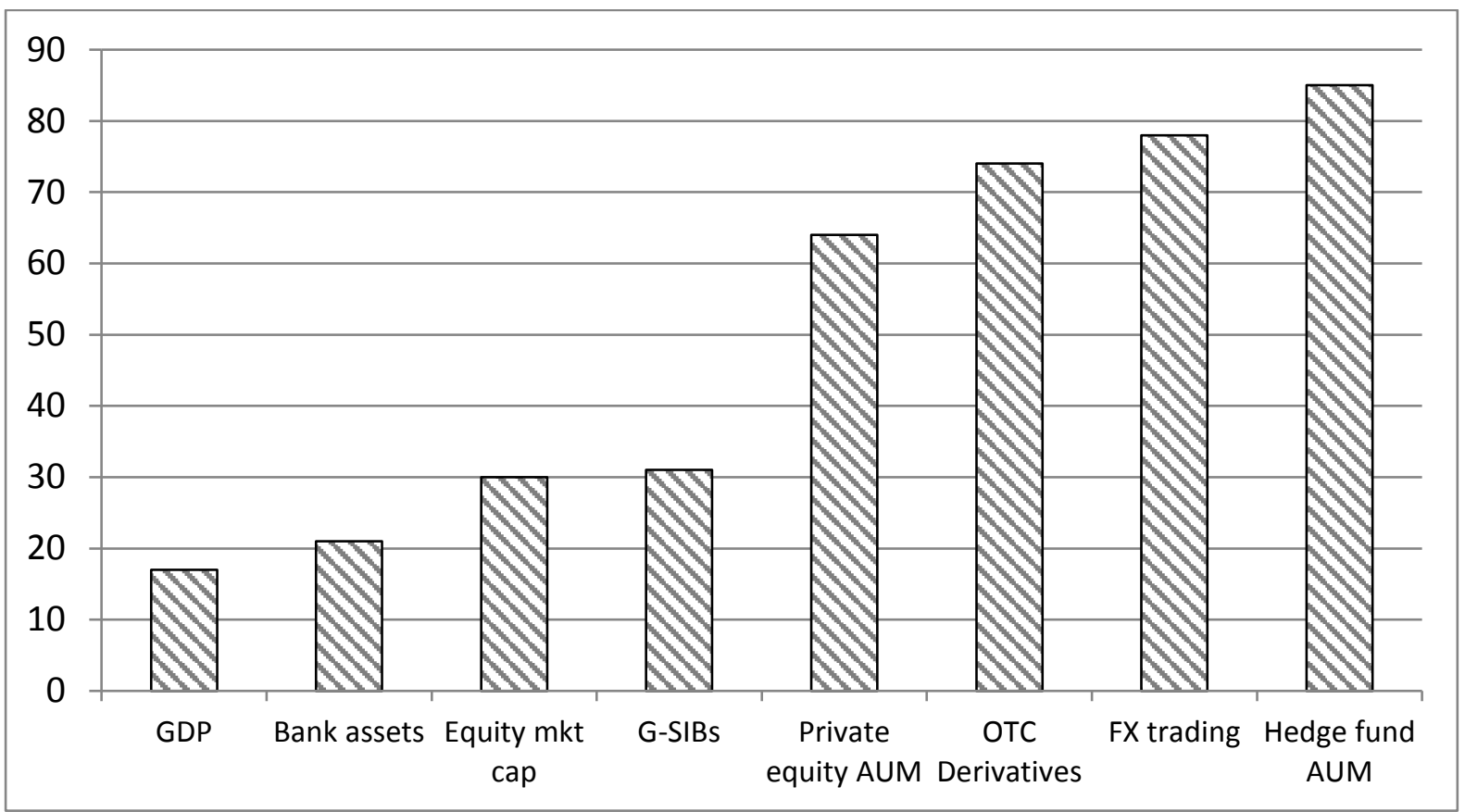

Notes: GDP and equity market data are from World Bank. Bank asset data are from ECB and PRA. G-SIB data are from FSB. Data on private equity assets under management, OTC derivatives transactions, FX trading and hedge fund assets under management from TheCityUK.

The outsize representation of the UK in the EU's financial market activity reflects the traditionally more market-oriented focus of the UK's domestic financial system than those of its continental European neighbours (Carlin and Mayer, 2003; Rajan and Zingales, 2003). However, the almost total dominance of the UK in certain wholesale market sectors is also 
consistent with the existence of agglomeration externalities (Sassen, 2001; Clark, 2002). That is, the co-location of providers yields spillover benefits through the availability of a deep and liquid pool of human capital and more rapid circulation of innovations and tacit knowledge. More specifically, there are complementarities in the co-location of wholesale market clearing infrastructure, because these permit net, rather than gross, exposures to be carried on participants' books (Wood, 2007; Cunliffe, 2016).

This pattern is also reflected in the EU's assessment of its priorities for the financial sector. In 2015, the European Commission announced an ambitious programme of reform known as the Capital Markets Union ('CMU'), intended to spur the growth of capital markets throughout the EU (European Commission, 2015). This is motivated by concern that the EU's financial system is excessively dependent on banks, which is thought to have an adverse impact on the financing of innovation, and to render the system very dependent on the stability of large financial institutions (ESRB, 2014; Langfield and Pagano, 2015).

Thus, the financial services nexus between the UK and the rest of the EU is of strategic importance to both sides. It is a particularly successful UK export industry, and-at least as respects wholesale markets-vitally important for the EU's diversification away from reliance on banking.

\section{Financial services and EU law}

The financial sector is one of the most globally interconnected components of most economies. It is at the same time one of the most heavily regulated sectors, the intensity of which has heightened since the financial crisis (Armour et al, 2016). The legal starting point, however, is that firms engaged in international activity must comply with regulation separately in each country in which they operate. There is a wide carve out under the WTO rules that gives governments power to restrict cross-border financial services on the basis of prudential controls. ${ }^{2}$ This consequently increases the cost of cross-border capital flows, with firms often needing to incorporate a subsidiary in each other jurisdictions in which they wish to operate, to ensure that each entity is compliant with the local regulatory regime.

\footnotetext{
${ }^{2}$ General Agreement on Trade in Services, Annex on Financial Services, para 2(a).
} 
A very different legal regime operates within the EU. The Member States have agreed to a common corpus of financial regulation, which since the financial crisis is written through EU-level sectoral agencies (Lamandini and Muñoz, 2016; Moloney, 2016b). In return, financial services firms that obtain authorisation within this single rule-book from the national competent authority ('NCA') in their country are then free to offer services throughout the EU Member States without any need for further local authorisations. This is known as the 'financial services passport'. Technically, there are many separate passports available under different pieces of financial services legislation, but they operate in an additive way, and EU law encompasses so much of financial services, that from most firms' perspective, the consequence is simply that whatever they are locally authorised to do, they are authorised throughout the EU. The potential loss of this ability to 'passport' services throughout the EU is at the centre of the financial sector's concerns over Brexit.

\section{3. 'Soft' Brexit and financial services}

It has become commonplace to refer to 'soft' and 'hard' versions of Brexit. 'Soft' Brexit is taken for these purposes to mean that UK leaves the EU but remains a member of the European Economic Area ('EEA') and hence enjoying access to the single market. This would put the UK in the same position as. The UK is currently an EEA member by virtue of its EU membership, so it seems likely that soft Brexit would technically require the UK to 're-join' the 1994 EEA Agreement, ${ }^{3}$ which governs relations between the EU and the three non-EU members, Norway, Iceland and Liechtenstein. ${ }^{4}$ Signing the EEA Agreement entails acceptance of the single market's 'four freedoms': goods, persons, services and capital. Moreover, the EEA requires contracting parties to enact into their domestic law most of the EU's acquis-as set out in the 22 Annexes to the EEA Agreement (Armour, 2016). ${ }^{5}$ The EEArelevant EU measures include those pertaining to company law and financial services. ${ }^{6}$ Consequently, were the UK to (re)join the EEA, UK-authorised financial services firms would

\footnotetext{
${ }^{3}$ This could itself be the subject of delay. One way to expedite it would be for the UK to re-join the European Free Trade Association (EFTA), which negotiates shared free trade agreements with third countries on behalf of its members, including the EEA Agreement.

${ }^{4}$ Switzerland is a member of EFTA but opted out of the EEA.

${ }^{5}$ The exceptions are the Common Agricultural Policy, the Customs Union, the Common Trade Policy, the Common Foreign and Security Policy, Justice and Home Affairs, and the European Monetary Union.

${ }^{6}$ EEA Agreement, Annexes IX and XXII.
} 
keep their EU passports. Moreover, UK-registered companies founded by entrepreneurs in other EU member states (of which there may be upwards of 100,000 ) would continue to have their existence recognised by other EU jurisdictions (Armour, Knapp and Winner, 2016).

The (formidable) obstacle to soft Brexit is that acceptance of the 'four freedoms' includes continued free movement of persons, an anathema to those who have championed Britain's departure from the EU. However, even if this obstacle were somehow to be overcome, the EEA model would still have two significant drawbacks for UK financial services.

First, while the UK would need to implement EEA-relevant EU rules, it would no longer get any say over their content (Moloney, 2016a). As an EU member, the UK has been a highly influential participant in the legislative process (Ferran, 2016a; Evans, 2016). As an EEA member, the UK would not only lose its internal influence on EU rule-making, but by being required to implement those rules, would not gain any external influence in the form of the ability to adopt alternate rules.

Second, the 'transplantation' of EU legislation into the laws of EEA members is not automatic; rather, those members must each consent to enact it into their domestic laws. This can lead to a lag between the enactment of EU laws and their EEA adoption, which appears to move at the pace of the slowest member state. There have been particular problems with post-crisis EU financial regulation. The new European System of Financial Supervision ('ESFS'), introduced in 2010, established EU-level agencies with delegated authority to write binding rules (European Commission, 2014). Implementing this created constitutional difficulties for some EEA members, which took six years to be resolved. Because the ESFS is embedded in all subsequent financial services regulations produced by the EU, this meant that until late 2016, none of the EU's post-crisis financial regulation was applicable in non-EU EEA signatories (EFTA, 2016).

These two problems mean that soft Brexit does not look a promising avenue for UK financial services, even if the immigration issue were somehow to be overcome (Armour, 2016; Ferran, 2016a). 


\section{Bilateral agreement outside the single market}

'Hard' Brexit is understood to mean an outcome in which the UK is a member neither of the EU nor the EEA. Given the level of UK-EU activity described above, there are clear benefits to both sides in coming to some sort of bilateral agreement regarding financial services. At this stage, little can usefully be said about the likely scope of such an agreement. In the remainder of this paper, we will focus on three cognate issues: (i) possible precedents; (ii) the 'outside' option for the UK if no agreement is forthcoming; and (iii) the desirable scope of such an agreement.

The existing precedents for bilateral agreements with the EU do not look promising. Switzerland and the EU have agreed a wide-ranging bundle of bilateral measures (Swiss Federal Department of Foreign Affairs, 2016). These cover free trade in goods, but generally not services, although the are particular measures on certain financial services, including non-life insurance (Hoffman, 2016). However, the price for these agreements is that the EU requires Switzerland to accept the free movement of EU citizens, which would clearly be unappealing to UK voters. In contrast, the recently-negotiated Comprehensive Economic and Trade Agreement ('CETA') between Canada and the EU does not entail any commitment on Canada's part to free movement of persons, but its provisions on financial services do not extend anywhere near the 'passport' recognition enjoyed by firms authorised within the EU. ${ }^{7}$ Moreover, CETA took seven years to negotiate, and notoriously nearly failed to be ratified by EU Member States.

However, the UK's bargaining position is quite unlike that of Switzerland or Canada, so these precedents are not especially illuminating. It is perhaps more helpful to consider the impact on financial services if the UK simply leaves the single market without any such agreement. This will help to identify what is at stake if agreement is not reached, and the strength of the parties' bargaining positions.

\section{The outside option: 'Hard' Brexit}

The cessation of EU membership will mean that the UK immediately becomes a third country'. The entitlements of the UK and its citizens under the EU Treaties qua EU Member

\footnotetext{
${ }^{7}$ Comprehensive Economic and Trade Agreement (CETA), Chapter 13.
} 
State will cease. This will mean that UK firms will no longer be able to rely on the freedom of establishment, or on EU passporting rights under financial services legislation. ${ }^{8}$

Except where specific arrangements have been made, the European single market is largely irrelevant as respects third country firms. That is, such firms must obtain authorisation under the regulatory regimes of each Member State in which they wish to operate: a decentralised model of state-by-state authorisation, ${ }^{9}$ very much like before the EU existed. EU law only intrudes in a negative way: most EU financial services legislation contains provisions prohibiting member states from offering more favourable treatment to third country firms than is provided for under the EU regime for Member State firms. Thus, the EU law rules provide a floor for third country firms' compliance obligations, preventing any Member State from offering a lax 'back door' to the single market. Yet there is nothing to stop Member States from discriminating against third country firms by imposing more exacting standards than for EU firms.

This rather unpromising terrain has been reshaped quite considerably, however, since the financial crisis. This period has seen a ramping-up in both the scope and intensity of international norms in financial regulation (Brummer, 2015). There has also been a shift in emphasis in financial regulation toward financial stability (Armour et al, 2016). Because the preservation of financial stability necessitates international cooperation, and because differential regulation increases the costs of trade under a traditional decentralised authorisation framework, there has been a parallel shift to multilateral production of new standards, through a new international organisation established by the G20, the Financial Stability Board ('FSB'). As a by-product, firms in third countries compliant with FSB guidance are now subject to rules that are substantially similar to those in the EU.

\footnotetext{
${ }^{8}$ At the same time, any access to non-EU financial services markets that UK firms currently enjoy under EUnegotiated arrangements will also cease, and so will need to be separately renegotiated (Ferran, 2016a). For the purposes of this discussion, we will focus on the effects on UK-EU activity.

${ }^{9}$ One apparent exception is the right to free movement of capital, which the EU Treaty expressly extends to movements between Member States and third countries: Treaty on the Functioning of the European Union ('TFEU'), Art 63. However, this provides no real benefit to third country financial services firms, because the provision has been interpreted narrowly by the Court of Justice such that where it overlaps with other treaty freedoms - such as the freedom of establishment-that do not extend to third countries, precedence should be given to the narrower provision (Schön, 2016). Consequently, financial services firms cannot rely on the free movement of capital to conduct business in the EU, as this activity is covered by the freedom of establishment, which does not extend to third country firms: Case C-452/04, Fidium Finanz AG $v$ Bundesanstalt für Finanzdienstleistungsaufsicht [2006] ECR I-09521, ECLI:EU:C:2006:631.
} 
These developments have also given the EU reason to rethink its traditional decentralised authorisation model for third country firms. Increasing the level of required scrutiny brings increased costs for each national authorisation, and decentralised decisionmaking makes it harder to control systemic risk (Cunliffe, 2016; Gleeson, 2016). The result has been an emerging, and still-evolving, body of rules known loosely as third country equivalence' (or '3CE') provisions (Ferran, 2016b). In essence, these provide for centralised authorisation decisions for third country firms as respects certain aspects of the EU's financial regulation regime. Relevant third country firms are thereby exempted from national authorisations with respect to rules covered by the relevant third country equivalence framework.

Three general points should be made about the application of 3CE. First, it is not so much a general framework as a lattice of many specific regimes that operate together. Second, the scope of, goals for, and associated processes for making relevant determinations differ from regime to regime: the devil lies in the detail. The European Commission maintains a list of current 3CE determinations, which details 39 different equivalence regimes under 14 different pieces of EU financial services legislation (European Commission, 2016). Third, 3CE is a moving target. New provisions are continually being added, and the way in which the 3CE processes are framed is also developing over time. These features make understanding the likely post-Brexit 3CE picture a complex and fastchanging endeavour. With these caveats in mind, it is worth making a few general observations about the likely operation of 3CE. We begin with the process of making a determination, and then turn to the scope of the relevant effects.

\section{Third country equivalence: process}

The key precondition to the application of a 3 CE regime is that there must be an authoritative determination that the third country's regulatory regime is equivalent to the EU regime. ${ }^{10}$ This is generally done by the Commission, increasingly following an assessment by the relevant European Supervisory Authority. Under the investment services regime, for example, such an equivalence determination has three components: (i) substantive equivalence: that the third country rules have equivalent effect to the relevant EU law rules;

${ }^{10}$ MiFIR, Arts 46(2)(a). 
(ii) compliance: that the legal and supervisory arrangements in the third country ensure that firms authorised there actually comply with the legal rules there; and, in some cases (iii) reciprocity: that the third country's legal framework provides for reciprocal recognition of EU firms. ${ }^{11}$

The UK government has announced that its likely strategy on exit from the EU will be a wholesale enactment of all previously-binding EU law into domestic UK law. It follows that, at the point of exit, the UK will have in place a body of financial regulation that necessarily will be substantively equivalent to EU law. ${ }^{12}$ The UK's FCA and PRA have far larger enforcement budgets than any other EU member state's financial regulators, which should suffice to meet the Commission's enquiries regarding compliance. And it will naturally be in the UK government's interests to agree, where necessary, to reciprocity for EU financial services firms wishing to do business in the UK.

There is a widely-held fear that the process of determining equivalence may become politicised in the context of a messy Brexit negotiation. Ironically, this fear likely underappreciates the merits of leaving decisions to technocrats, which is precisely what the democratically-opaque structure of the Commission, and a fortiori, the delegation of the initial assessment to the ESAs, is intended to achieve (Moloney, 2016). Table 2 shows the third countries for which equivalence determinations have been made by the Commission as respects a range of existing 3 CE regimes. As can be seen, the lists consist of subsets of G20 countries and additional financial centres. Each of these countries has a common interest with the EU in the relevant sectors. While bureaucrats at the Commission are unlikely to feel much sympathy towards the UK, it would surely be inconsistent with both the EU's interests and the vision of the EU project for them to treat the UK appreciably differently to this list of existing partners.

Table 2: Third countries for which equivalence determinations have been made

\footnotetext{
11 Ibid, Art 47(1).

12 There will nevertheless be an enormous amount of legal work necessary simply to 'convert' the EU legislation to a format that will actually function on a stand-alone basis. This will include relatively straightforward but high-frequency matters such as changing the identity of rule-making and supervisory bodies (eg from ESMA to the FCA) and changing the applicable procedures for implementing secondary legislation. It should also include responses to some rather more profound challenges, such as the introduction of a parallel domestic mechanism for responding to, and where appropriate implementing, post-exit updates to the EU regime, and the status and effect of post-exit CJEU decisions on domestically-internalised rules.
} 


\begin{tabular}{|l|l|l|l|}
\hline Sector & Measure & G20 Countries & Financial centres \\
\hline Banking & CRD IV & $\begin{array}{l}\text { Australia, Brazil, Canada, } \\
\text { China, India, Japan, } \\
\text { South Korea, Mexico, } \\
\text { Saudi Arabia, South } \\
\text { Africa, USA }\end{array}$ & $\begin{array}{l}\text { Hong Kong, } \\
\text { Singapore and } \\
\text { Switzerland }\end{array}$ \\
\hline Insurance & Solvency II & $\begin{array}{l}\text { Australia, Brazil, Canada, } \\
\text { Japan, Mexico, USA. }\end{array}$ & $\begin{array}{l}\text { Bermuda, } \\
\text { Switzerland }\end{array}$ \\
\hline Prospectuses & PD & Turkey & Israel \\
\hline Credit Ratings & CRA Regulation & $\begin{array}{l}\text { Argentina, Australia, } \\
\text { Brazil, Canada, Japan, } \\
\text { Mexico, USA }\end{array}$ & $\begin{array}{l}\text { Hong Kong, } \\
\text { Singapore }\end{array}$ \\
\hline Derivatives & EMIR & $\begin{array}{l}\text { Australia, Canada, South } \\
\text { Korea, Mexico, South } \\
\text { Africa and the US }\end{array}$ & $\begin{array}{l}\text { Hong Kong, } \\
\text { Singapore and } \\
\text { Switzerland }\end{array}$ \\
\hline
\end{tabular}

A more plausible concern is whether the Commission will have completed the necessary equivalence determinations by the time the UK's two-year Article 50 period is completed. Neither the third country, nor its firms, have any right to compel the Commission to start the process of making an equivalence determination, even if the third country would manifestly meet the criteria. Bearish commentators note, for example, that it took four years from the coming into force of EMIR for the EU to accept the equivalence of the US regime on central counterparties for derivatives. While this may not be the best comparator, given that the relevant US and EU rules had a number of material differences, more concerning is the fact that the very earliest equivalence decisions under EMIR, for Australia, Hong Kong and Singapore, took two years from when the legislation came into force. Moreover, the Swiss experience has apparently been one of frustration over delays on the part of the Commission (Hoffmann, 2016). In particular, an extension to a third country passport regime under the Alternative Investment Fund Managers Directive, which was originally expected to be rolled out after July 2015 , is still in limbo at the date of writing, apparently mired in concerns at the Commission about the impact of Brexit despite favourable opinions from ESMA regarding a list of financial centres including Switzerland (ESMA, 2016).

This suggests that an important item in the UK's Article 50 negotiations should be getting the Commission to begin its assessment of the UK regime at the time of triggering Article 50. This would give enough time for a smooth transition: if the process does not 
commence until after exit, this would leave a significant hiatus in wholesale market provision. There is precedent for the application of equivalence regimes on a 'pre-emptive' basis, as was done in the case of the Solvency II Directive for insurance, before it came into force (Scarpetta and Booth, 2016).

As well as an equivalence determination from the Commission, there must be cooperation agreements in place between the third country's authorities and both the relevant European Supervisory Agency and relevant NCAs in EU Member States. ${ }^{13}$ The UK can take the initiative in seeking to expedite such arrangements pre-emptively during the Article 50 negotiating period, however.

A third concern relates to the future beyond the short term. Equivalence must be reviewed periodically, and an initial decision in favour of the UK may be withdrawn by the Commission at will. While the regimes will be equivalent on exit, they may rapidly diverge. On the one hand, the EU has produced new legislation governing the financial sector at an astonishing rate since the financial crisis, and this shows no sign of abating. On ceasing to be hardwired into the system, the UK will rapidly fall behind-as has happened with the nonEU EEA countries-unless it adopts a mechanism for automatic implementation of new EU financial regulation initiatives into domestic law.

So far, no country has ever had an equivalence decision in its favour by the Commission withdrawn. While the UK must prospectively commit to apply updates to EU financial services law in order to maintain equivalence securely, this would be quite different from soft Brexit. The commitment need only be as respects (relevant aspects of) financial services law, not the general legal framework of the single market. And the increasing growth in coordination of international standard-setting through the FSB means that if the UK maintains strong links there, ${ }^{14}$ it may be able to continue to influence the regulatory agenda-no longer through the EU process directly, but at a level above the EU. Of course, the EU may decide to 'gold plate' FSB standards in ways that the UK does not wish to follow-as has happened recently, for example, in relation to bank executive compensation (Armour et al, 2016: Ch 17). Some commentators have floated the idea of a

\footnotetext{
${ }^{13}$ See eg MiFIR Arts 39, 46(2)(c), 47(2).

${ }^{14}$ Mark Carney, the Governor of the Bank of England, is currently also Chair of the FSB.
} 
'parallel regime' within the UK, one EU-compliant and one not (Ferran, 2016a, 2016b)-an approach currently being pioneered by small jurisdictions such as Guernsey.

\section{Third country equivalence: scope}

If the process of third country equivalence is workable, what would be the scope of its effect? As we shall see, there is alignment between the breadth of 3CE regimes and the areas in which the EU's financial sector currently labours under a comparative disadvantage. The 3 CE regimes are most extensive for wholesale financial markets, and least extensive for commercial banking, with retail markets and insurance falling in between.

Commercial Banking. EU legislation on banking regulation provides only very limited scope for $3 \mathrm{CE}$, and does not provide for any direct access to the EU by third country firms. There are 3CE provisions providing for coordination of supervision and for 'prudential equivalence'. However, none of these 3CE frameworks covers the provision of lending services by third country banks within the EU. Nor do they cover the operation of payment systems, or the operation of bank resolution and insolvency.

As we saw, banking is currently responsible for over half of the UK's intra-EU exports of financial services. This would likely be substantially impaired by hard Brexit, absent a change in the $3 C E$ regime. City practitioners quantify the at-risk revenues at $f 20$ billionthat is, most of the intra-EU exports detailed in Table 1. The big question going forward would be the extent to which the resources currently supporting intra-EU banking in the UK could be redeployed to other areas such as wholesale markets. Most obviously at risk would be the component of the UK banking sector made up of non-EU-headquartered banks that have established a UK subsidiary in order to benefit from the EU banking passport. These firms, which in 2015 had UK assets of $£ 1.32$ billion, or $14 \%$ of the UK banking sector, would see their reason for being in the UK vanish. Their parent companies would likely relocate these operations to other EU Member States such as Ireland or Luxembourg.

Insurance. EU insurance legislation contains an earlier and less elaborate 3CE framework than is featured in many subsequent legislative instruments. This reflects the fact that disagreements between the US and Europe over insurance regulation mean that 
there is not yet international consensus in the area (Evans, 2016), so the drivers for change discussed above have had less effect.

Like banking, the insurance 3CE provisions focus on supervisory coordination, especially the recognition of third country group supervision arrangements. Analogously to banking, it does not provide a framework for the provision if insurance services by third country firms into the EU. However, it does do so for reinsurance, through providing a 3CE mechanism for reinsurance supervision.

Unlike banking, the insurance industry already largely operates through subsidiaries in other European jurisdictions (Scarpetta and Booth, 2016). This means that the sector would have less to lose from hard Brexit. One exception is Lloyd's of London, which operates directly in other EU jurisdictions, and estimates that $11 \%$ of its revenues, or $£ 3$ billion, is at risk (Evans, 2016).

Retail markets. Retail markets comprise those financial products and services that may legally be offered to retail investors or consumers. There is very little scope for $3 C E$ in retail financial products: not for banking services, nor for investment funds or products, nor for investment advice or even brokerage services. This reflects in part the political sensitivity of access to EU retail investors, and in part the fact that there is, even within the EU, little in the way of cross-border retail financial service provision. For example, Santander Group, a Spanish-headquartered bank, operates a large retail banking business in the UK through a locally-capitalised subsidiary, Santander Bank plc (Santander UK plc, 2015; Santander Group, 2015). ${ }^{15}$

Wholesale financial markets. Most importantly, the MiFID II legislation coming into force at the beginning of 2018 (the Markets in Financial Instruments Directive II and associated Regulation) will introduce a so-called 'third country passport'. ${ }^{16}$ This will mean that eligible firms that register a branch in one EU Member State will be able to provide

15 The one exception to this picture is retail investment in securities listed on regulated markets. The prospectus regulation framework makes provision for 3CE with respect to prospectus disclosure requirements. Under the current legislation, this operates in a rather more decentralised way than other 3CE regimes.

${ }^{16}$ Markets in Financial Instruments Directive II ('MiFID II') and Markets in Financial Instruments Regulation ('MiFIR'). 
investment services and activities to sophisticated clients throughout the EU without any need for further authorisation. ${ }^{17}$

The third country passport will only cover transactions with sophisticated clients. ${ }^{18}$ For such persons, it will extend to all core investment banking activity, including brokerage, underwriting, M\&A advisory work, market making and proprietary trading. ${ }^{19}$ It will not, however, cover regular commercial lending, except insofar as this constitutes an 'ancillary service' to investment services and activities of these sorts. ${ }^{20}$ A potential drawback for firms using this regime is that they must offer clients the opportunity to have any legal disputes arising resolved in an EU Member State. ${ }^{21}$

Alongside MiFID II, there is already in place a series of 3CE frameworks under regulations introduced to govern various aspects of 'market infrastructure', including derivatives trading (on-exchange) and clearing (for OTC derivatives), securities financing transaction trade repositories and reporting requirements, and central securities depositaries. There is also in theory, a parallel 3CE regime for alternative investment fund managers (covering all non-retail investment funds), although as detailed above, its implementation appears to have become stuck in a holding pattern.

The breadth of the 3CE regimes in wholesale markets match the UK's comparative advantage, and the EU's comparative disadvantage, as respects financial services. This perhaps represents a great opportunity for the UK going forwards. Unfortunately, the 3CE regime for wholesale markets could equally well serve to open the UK up to further third country competition in the sector. If the 3 CE regime permits US-and perhaps Asianbased-firms to provide such services into the EU, then the EU's need for UK wholesale services would be significantly weakened. It also means there would cease to be a clear

\footnotetext{
17 There will be registration requirements associated with establishing such a branch (MiFID II, Art 39), including minimum capital requirements and the need for a bilateral cooperation agreement between the third country and the EU 'home branch' NCA.

${ }^{18} \mathrm{MiFIR,} \mathrm{Art} \mathrm{46(5).}$

${ }^{19}$ MifID II Annex I, Section A. See also ibid, Section B.

20 This means that while prime brokerage lending would be covered (as the loan is to a brokerage client to facilitate trading), the provision of loans to finance an M\&A transaction would not be (whereas underwriting a junk bond issue to finance an M\&A transaction would be covered).

${ }^{21}$ MiFIR, Art 46(6).
} 
regulatory rationale for US and other investment banks to remain located in London to pursue wholesale market-related activity. Why do so when the same services could be provided from the US?

Against this rather gloomy outlook, US President-elect Trump may yet be an unlikely saviour of the UK financial sector. Trump has promised to repeal significant parts of the Dodd-Frank Act, the flagship post-crisis legislation passed in the US in 2010. Early indications suggest he plans to follow through with this: Trump's appointee to oversee financial services strategy, Paul Atkins, is a hard-line advocate of deregulation. If this happens, then the Commission will be rather less likely to make an equivalence decision in favour of the US in respect of the MiFID II regime, and UK-based firms will retain a competitive advantage. A US retreat from regulation would also have an adverse impact on the work of the FSB, which has flourished in the presence of strong support from the US. A weakened FSB would reduce the UK's ability to influence EU regulation through this channel. As a result, the UK might end up half-way between two quite different regimes, with influence over neither. A twotrack regulatory regime would seem very worthwhile to pursue in that event.

\section{Conclusion}

Soft Brexit would require one of the parties soften their current stance on free movement, which seems unlikely. And hard Brexit would cause UK firms to lose their banking exports to the EU. The best outcome for the UK, given the preferences expressed by its voters, would be for a negotiated agreement on financial services that offers something more than the patchwork of 3CE provisions discussed above. The UK would want such an agreement to (i) provide a more enduring foundation for access by its firms than a unilateral equivalence determination by the Commission; (ii) to cover, in addition to wholesale markets, in order of priority, payment services, banking activity, and wholesale insurance. How far the UK gets towards this goal in the negotiations will likely depend at least in part on its outside option-hard Brexit.

In a hard Brexit scenario, there is a clear mutual interest in, and a legal framework within which to deliver, continued connectivity for wholesale markets and associated financial services. However, hard Brexit has many perils for UK financial services: likely loss of the current intra-EU banking exports, possible competition from the US in wholesale 
markets, and the risk of a disastrous hiatus if the Commission cannot be persuaded to begin work on its equivalence assessment soon enough to have a decision in place by the time the two-year Article 50 negotiating period ends. Yet the signalled change of direction in US financial regulation makes it less likely that the US will be a plausible alternative provider of the wholesale financial services the EU needs in its drive to stimulate capital markets. This in turn will underline the importance for the Commission to ensure the relevant equivalence decisions are in place by the time Brexit happens. On this analysis, the UK's outside option may not be disastrous.

\section{References}

Armour, John (2016), 'Brexit to the EEA: What Would it Mean?', Oxford Business Law Blog, July 2016. Armour, John, Dan Awrey, Paul Davies, Luca Enriques, Jeffrey N. Gordon, Colin Mayer and Jennifer Payne (2016), Principles of Financial Regulation (Oxford: OUP, 2016).

Armour, John, Vanessa Knapp and Martin Winner (2016), 'Corporate Citizenship and Brexit', working paper, October 2016.

Braddick, Katherine (2016), Evidence on 'Brexit and Financial Services' to House of Lords Select Committee on the European Union Financial Affairs Sub-Committee, 19 October 2016.

Brummer, Chris (2015), Soft Law and the Global Financial System: Rule Making in the $21^{\text {st }}$ Century (New York: Cambridge University Press, $2^{\text {nd }} e d$ ).

Carlin, Wendy and Colin Mayer (2003), 'Finance, Investment, and Growth' 69 Journal of Financial Economics 191-226.

Clark, Gordon (2002), 'London in the European Financial Services Industry: Locational Advantage and Product Complementarities' 2 Journal of Economic Geography 433-453.

Cunliffe, Sir Jon (2016), Evidence on 'Brexit and Financial Services' to House of Lords Select Committee on the European Union Financial Affairs Sub-Committee, 12 October 2016.

Evans, Huw (2016), Evidence on 'Brexit and Financial Services' to House of Lords Select Committee on the European Union Financial Affairs Sub-Committee, 12 October 2016.

European Commission (2014), 'Report from the Commission to the European Parliament and the Council on the operation of the European Supervisory Authorities (ESAs) and the European System of Financial Supervision (ESFS)', COM(2104) 509 final, Brussels 8 August 2014.

European Commission (2015), 'Building a Capital Markets Union', Green Paper, COM(2015) 63 final, 18 February 2015.

European Commission (2016), 'Equivalence Decisions Taken by the European Commission (as at 19/09/2016)'.

European Free Trade Association (EFTA) (2016), 'First package of acts on European Financial Supervisory Authorities incorporate into EEA Agreement', 30 September 2016, available at http://www.efta.int/EEA/news/First-package-acts-European-Financial-SupervisoryAuthorities-incorporated-EEA-Agreement-499496. 
European Securities and Markets Authority (ESMA) (2016), 'ESMA's Advice to the European Parliament, the Council and the Commission on the application of the AIFMD passport to non-EU AIFMs and AIFs', ESMA/2016/1140, 12 September 2016.

European Systemic Risk Board (ESRB) (2014), 'Is Europe Over-Banked?', Advisory Scientific Committee Report No 4, June 2014.

Financial Conduct Authority (FCA) (2016), Written submission to House of Lords Select Committee on the European Union Financial Affairs Sub-Committee, 17 October 2016.

Ferran, Eílis (2016a), Evidence on 'Brexit and Financial Services' to House of Lords Select Committee on the European Union Financial Affairs Sub-Committee, 7 September 2016

Ferran, Eílis (2016b), 'The UK as a Third Country Actor in EU Financial Services Regulation', University of Cambridge Faculty of Law Working Paper No 47/2016, September 2016.

Gleeson, Simon (2016), Evidence on 'Brexit and Financial Services' to House of Lords Select Committee on the European Union Financial Affairs Sub-Committee, 14 September 2016

Hoffmann, Stefan (2016), Evidence on 'Brexit and Financial Services' to House of Lords Select Committee on the European Union Financial Affairs Sub-Committee, 12 October 2016.

Kirby, Simon, MP (2016), Evidence on 'Brexit and Financial Services' to House of Lords Select Committee on the European Union Financial Affairs Sub-Committee, 19 October 2016.

Lamandini, Marco and David Ramos Muñoz (2016), EU Financial Law: An Introduction (Milan: Wolters Kluwer, 2016).

Langfield, Sam and Marco Pagano (2015), 'Bank Bias in Europe: Effects on Systemic Risk and Growth' ECB Working Paper No 1797, May 2015.

Moloney, Niamh (2016a), 'Financial Services, the EU, and Brexit: An Uncertain Future for the City?', 17 German Law Journal 75-82.

Moloney, Niamh (2016b), House of Commons Economy Committee, 'The Impact of the EU Exit on Financial Services', 11 October 2016.

Rajan, Raghuram and Luigi Zingales (2003), 'Banks and Markets: The Changing Character of European Finance' in Vítor Gaspar, Philipp Hartmann and Olaf Sleijpen (eds), The Transformation of the European Financial System (Frankfurt: European Central Bank), 123-168.

Santander Group (2016), 2015 Annual Report.

Santander UK plc (2016), 2015 Annual Report.

Sassen, Saskia (2001), The Global City: New York, London, Tokyo (Princeton, NJ: Princeton University Press, $2^{\text {nd }}$ ed).

Scarpetta and Booth (2016), How the UK's Financial Services Sector Can Continue Thriving After Brexit, Open Europe Report 10/2016.

Schön, Wolfgang (2016), 'Free Movement of Capital and Freedom of Establishment' 17 European Business Organization Law Review 229-260.

Swiss Federal Department of Foreign Affairs (FDFA) (2016), 'The Major Bilateral Agreements Switzerland-EU', September 2016, available at https://www.eda.admin.ch/content/dam/dea/en/documents/folien/FolienAbkommen en.pdf.

Wood, Philip (2007), Set-off and Netting, Derivatives, Clearing Systems (London: Sweet \& Maxwell). 